\title{
Effect of COD/N ratio on nitrate removal in horizontal subsurface flow constructed wetlands
}

\author{
Qi Yin ${ }^{1, a}$, Wenrui Guo ${ }^{1, b}$, Yue Wen ${ }^{1, c}$ and Qi Zhou ${ }^{1, d}$ \\ ${ }^{1}$ College of Environmental Science and Engineering, Tongji University, Shanghai, China. \\ aqiyin1991@126.com, bguowenrui0515@126.com, 'weny@tongji.edu.cn, dzhouqi@tongji.edu.cn
}

Keywords: Horizontal subsurface flow constructed wetlands (HSSF CWs), cattail fermentation broth, COD/N ratio, nitrate removal.

\begin{abstract}
In this study, four laboratory-scale horizontal subsurface flow constructed wetlands (HSSF CWs) were designed to reveal the effects of cattail fermentation broth and Typha latifolia on nitrate removal. The results showed that both the addition of cattail fermentation broth and the presence of Typha latifolia could improve the nitrate removal rate. As $\mathrm{COD} / \mathrm{N}$ ratio increased from 0 to 3 , the nitrate removal rate attributed to the plant increased from 0.09 to $0.29 \mathrm{~g} \mathrm{~N} \mathrm{~m}^{-3} \mathrm{~d}^{-1}$, but the nitrate removal proportion decreased from $27.3 \%$ to $10.7 \%$, and denitrification was always the dominant nitrate removal mechanism.
\end{abstract}

\section{Introduction}

Constructed wetlands (CWs) have a high potential for tertiary treatment in developing countries due to their cost-effective, simple operation and environmentally friendly. In horizontal subsurface-flow constructed wetlands (HSSF CWs), the denitrification potential is considered to be high, as it can provide anoxic or anaerobic conditions [1]. However, the influent wastewater carbon is mostly oxidized in the aeration processes [2] and the internal carbon from rhizosphere is insufficient for denitrification [3]. Therefore, an alternative carbon source is needed to drive the denitrification.

Various carbon sources were used to improve the denitrification performance in carbon-limited wetlands, including glucose, fructose, soils and plant biomass [4, 5]. And among the various carbon sources, plant biomass could be used as an alternative carbon source because of the low cost, renewable biomass and wide availability [6]. However, adding the plant biomass into the CWs directly also has some disadvantages. On the one hand, it will cause the unstable carbon supply that presents the characteristics of carbon source is excessive in the initial stage but insufficient in the terminal stage [6]. On the other hand, it will cause the low effective utilization of carbon source for denitrification [7]. Fortunately, one of the effective improvements is to use the fermentation broth of the plant harvested in HSSF CWs as carbon source to enhance denitrification.

The objectives of this study were: (1) to investigate the effects of cattail fermentation broth and Typha latifolia on nitrate removal; (2) to assess the effect of cattail fermentation broth on the effluent COD in HSSF CWs.

\section{Methods}

\subsection{Characterization of Fermentation Experiments.}

Five fermentation tanks were conducted in our laboratory, and their effective volumes are $10 \mathrm{~L}$. The fermentation mixtures in each tank contained $100 \mathrm{~g}$ (dry weight, DW) of raw cattail litter and $7 \mathrm{~g}$ (dry weight, VSS) of inoculated sludge with distilled water added to the working volume. And the fermentation tanks were then incubated at $35 \pm 0.5^{\circ} \mathrm{C}$ and the $\mathrm{pH}$ values were adjusted to $7.0 \pm 0.1$ by $5 \mathrm{M} \mathrm{NaOH}$ and $5 \mathrm{M} \mathrm{HCl}$ every $12 \mathrm{~h}$ while mixing at $150 \mathrm{rpm}$ (rotations per minutes) for 20 days.

\subsection{Experimental Design and Operation.}

Four continuous flow HSSF CW microcosms were applied in the study. i.e. Unplanted and non-carbon addition unit (W1), planted and non-carbon addition unit (W2), unplanted and carbon addition unit (W3), planted and carbon addition unit (W4). With this setup, the effects of cattail 
fermentation broth without (comparison between W1 and W3) or with (comparison between W2 and W4) plant and plant without (comparison between W1 and W2) or with (comparison between W3 and W4) cattail fermentation broth on nitrate removal in CWs were assessed by comparing the results from these four microcosms.

The HSSF CW microcosms (length: $1.5 \mathrm{~m}$, width: $0.4 \mathrm{~m}$, height: $0.6 \mathrm{~m}$ ) were located in a controlled greenhouse environment $\left(25 \pm 2{ }^{\circ} \mathrm{C}\right)$. Each cuboid included the inlet section $(0.15 \mathrm{~m})$, working section $(1.2 \mathrm{~m})$, and outlet section $(0.15 \mathrm{~m})$. All the microcosms were filled with gravel $(\phi$ $8-13 \mathrm{~mm}$, porosity $=0.4$, height: $0.5 \mathrm{~m}$ ), and the plant (Typha latifolia) density in each planted microcosm was approximately 20 plants $/ \mathrm{m}^{2}$. Sewage flowed into or out of the wetland microcosms through water distribution areas filled with gravel $(\phi 10-20 \mathrm{~mm})$.

The secondary effluent was collected from a neighboring wastewater treatment plant (in Shanghai, China) and spiked with $\mathrm{KNO}_{3}$, in order to achieve a final nitrate concentration of $15 \mathrm{mg} \mathrm{N} \mathrm{L}^{-1}$. While the fermentation supernatant was fed by a positive displacement pump to achieve the target added COD-to-influent nitrate ratios (COD/N ratios) between 1 and 4 in $\mathrm{W} 3$ and $\mathrm{W} 4$ microcosms. And the hydraulic retention times (HRTs) of the wetland microcosms were $4 \mathrm{~d}$.

\subsection{Sampling and analysis.}

Regular influent and effluent grab samples were collected every five days from each wetland microcosm. Samples for $\mathrm{COD}, \mathrm{NH}_{4}-\mathrm{N}, \mathrm{NO}_{3}-\mathrm{N}$ and $\mathrm{TN}$ were analyzed according to standard methods [8]. The analyses of cellulose, hemicelluloses, lignin, reducing sugar, soluble protein as well as VFAs were the same as described in the previous publication [6].

\section{Results and Discussion}

\subsection{Characterization of cattail fermentation broth.}

Cellulose (28.6\%), hemicellulose (13.7\%) and lignin (9.3\%) were the main constituents of cattail litter. The lignocellulose can be hydrolyzed to reducing sugars, and then the monosaccharides are converted to VFAs through the anaerobic microbial metabolism [9]. In fermentation experiments, 10 g DW L ${ }^{-1}$ plant litter was added in each fermentation tank. After fermentation, the average COD, $\mathrm{NH}_{4}-\mathrm{N}$ and $\mathrm{TN}$ concentrations in cattail fermentation broth were $2467,6.4$ and $15.6 \mathrm{mg} \mathrm{L}^{-1}$, respectively. Accordingly, the calculated COD conversion factor of cattail fermentation broth is about $0.25 \mathrm{~g} \mathrm{COD} \mathrm{g}^{-1} \mathrm{DW}$ cattail litter. In addition, the calculated average COD/TN ratio in cattail fermentation broth was 158 . These results indicated that using cattail fermentation broth as additional carbon source could greatly improve the quality and quantity of available carbon source.

\subsection{Nitrate Removal.}

\subsubsection{Effect of Cattail Fermentation Broth on Nitrate Removal.}

The influent and effluent nitrate concentrations were shown in Fig. 1. The calculated nitrate removal rates in $\mathrm{W} 1$ and $\mathrm{W} 2$ microcosms were $0.24 \mathrm{~g} \mathrm{~N} \mathrm{~m}^{-3} \mathrm{~d}^{-1}$ and $0.33 \mathrm{~g} \mathrm{~N} \mathrm{~m}^{-3} \mathrm{~d}^{-1}$ over the period of this study, respectively. The nitrate removal rates in $\mathrm{W} 3$ microcosm were $0.95,1.71,2.42$ and 3.72 $\mathrm{g} \mathrm{N} \mathrm{m}^{-3} \mathrm{~d}^{-1}$, respectively, while the $\mathrm{COD} / \mathrm{N}$ ratios were adjusted between 1 and 4 , which were 4.0-15.5 folds of those measured in $\mathrm{W} 1$ microcosm. The nitrate removal rates in $\mathrm{W} 4$ microcosm were $1.17,1.98,2.71$ and $3.74 \mathrm{~g} \mathrm{~N} \mathrm{~m}^{-3} \mathrm{~d}^{-1}$, respectively, while the $\mathrm{COD} / \mathrm{N}$ ratios were adjusted between 1 and 4, which were 3.5-11.3 folds of those measured in W2 microcosm. These results showed that using cattail fermentation broth as additional carbon source could greatly improve the nitrate removal rate, and with the increase of $\mathrm{COD} / \mathrm{N}$ ratio, the nitrate removal rate increased. Previous studies showed that most denitrifying bacteria are chemoheterotrophs, and the quality and quantity of available carbon sources were used as indexes of carbon bioavailability to evaluate the influence of carbon on nitrate removal $[6,10]$. Given that the reducing sugar $(2.2 \%)$, soluble protein $(4.3 \%)$ and VFAs (86.2\%) were the main components of additional carbon source in this study, the denitrifying bacteria can quickly use these organic matters for denitrification. In addition, the increase of COD/N ratio in $\mathrm{W} 3$ and $\mathrm{W} 4$ microcosms might favor the denitrifying bacteria in other ways, e.g. the DO concentrations and ORP conditions in HSSF CWs are lowered by the higher heterotrophic activity and limited diffusion condition [11]. 
Wen et al. [6] reported that the adaptation period for denitrification and nitrate removal in CWs could be shorten with plant biomass addition, but it has the disadvantage of unstable carbon supply. Chen et al. [7] further found that the relative contribution of denitrification bacteria to the COD consumption was approximately 8.4-9.2\%, suggesting the low effective utilization of carbon source for denitrification, due to the excessive plant carbon supply in the initial stage. Obviously, in this study, using cattail fermentation broth as additional carbon source successfully solved the problem of unstable carbon supply, thus achieving a stable nitrate removal rate. Furthermore, the availability of carbon source for denitrification can also be improved by adjusting the COD/N ratio.

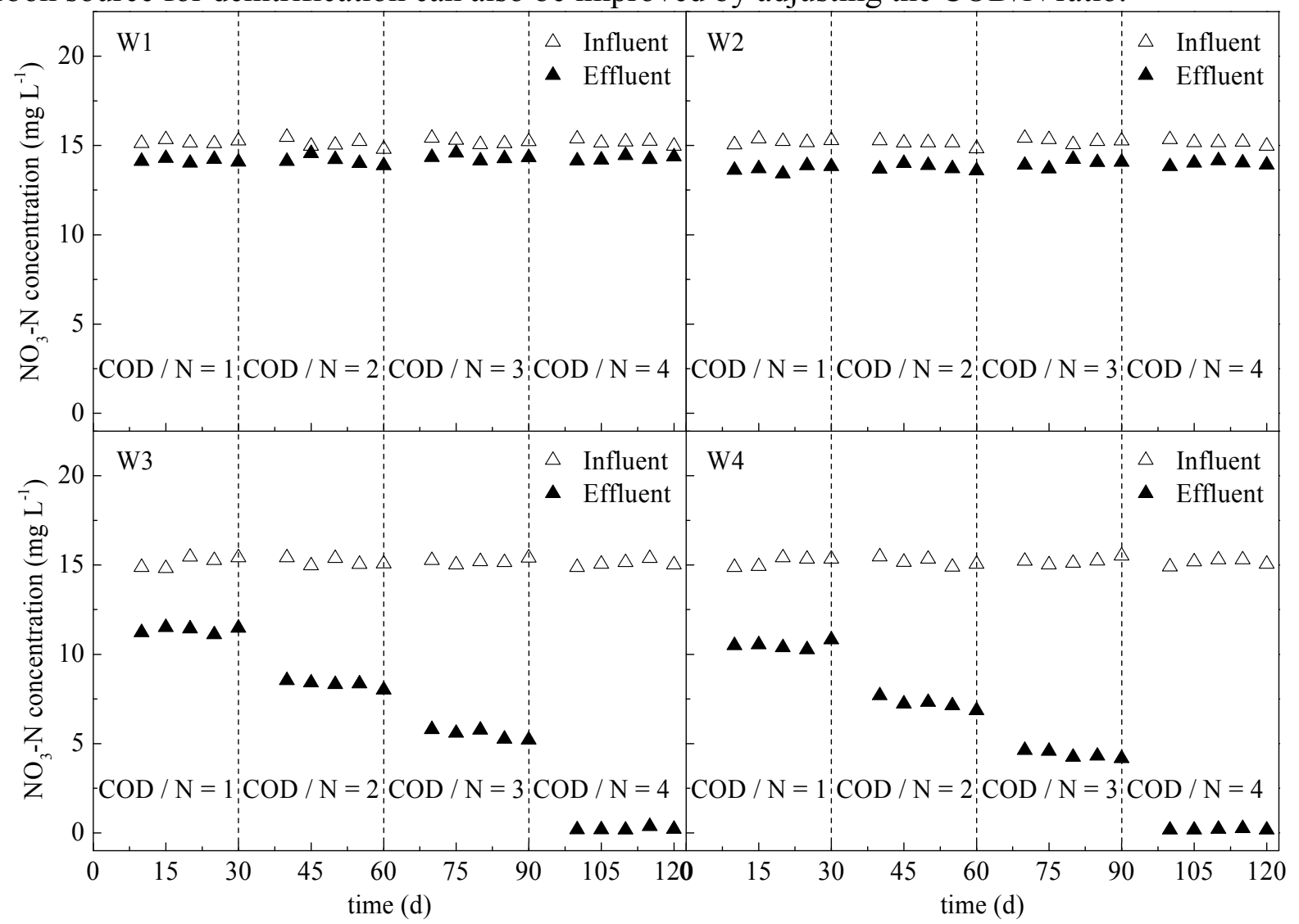

Fig. 1 Influent and effluent $\mathrm{NO}_{3}-\mathrm{N}$ concentrations in four Wetland microcosms

\subsubsection{Effect of Plant on Nitrate Removal.}

Compared with $\mathrm{W} 1$, the nitrate removal rate increased $0.09 \mathrm{~g} \mathrm{~N} \mathrm{~m}^{-3} \mathrm{~d}^{-1}$ in W2. Accordingly, 0.09 $\mathrm{g} \mathrm{N} \mathrm{m}^{-3} \mathrm{~d}^{-1}$ of nitrate removal could be attributed to the plant, and the presence of plant accounted for $27.3 \%$ of the nitrate removal in this study, suggesting that the plant could improve the nitrate removal in CWs. This could be the consequence of release of organic carbon from the roots and supply of attachment sites for denitrifying bacteria which stimulated the denitrification as the growth of the plant [12]. And the ability of plant uptake may be another explanation [13].

Compared with $\mathrm{W} 3$, the nitrate removal rate increased $0.22-0.29 \mathrm{~g} \mathrm{~N} \mathrm{~m}^{-3} \mathrm{~d}^{-1}$ in $\mathrm{W} 4$, while the $\mathrm{COD} / \mathrm{N}$ ratios were adjusted between 1 and 3. Accordingly, $0.22-0.29 \mathrm{~g} \mathrm{~N} \mathrm{~m}^{-3} \mathrm{~d}^{-1}$ of nitrate removal could be attributed to the plant, which were 2.4-3.2 folds of those measured in W2 microcosm. These results showed that the nitrate removal rate attributed to the plant was much higher in cattail fermentation broth added wetland microcosms. This is due to the use of cattail fermentation broth enhanced the denitrification rate, which reducing the nitrate concentrations in wetland microcosms. And the lower nitrate concentrations in wetland microcosms increased the amount of carbon released from the plant roots [14], which further enhanced the denitrification in HSSF CWs. As a result, the nitrate removal rate attributed to the plant increased with the increase of COD/N ratio (1-3).

However, the presence of plant accounted for $18.8 \%, 13.6 \%$ and $10.7 \%$ of the nitrate removal in $\mathrm{W} 4$, respectively, while the $\mathrm{COD} / \mathrm{N}$ ratios were adjusted between 1 and 3 . This suggested that the nitrate removal proportion attributed to the plant was really low and was decreased with the increase 
of $\mathrm{COD} / \mathrm{N}$ ratio (1-3). Besides, although the use of cattail fermentation broth can enhance root secretion, the indirect enhancement for denitrification was much lower than the direct enhancement, as indicated that the indirect enhance rate was also much lower than the direct enhance rate. Meanwhile, microbial denitrification was always the dominant nitrate removal mechanism in cattail fermentation broth added CWs.

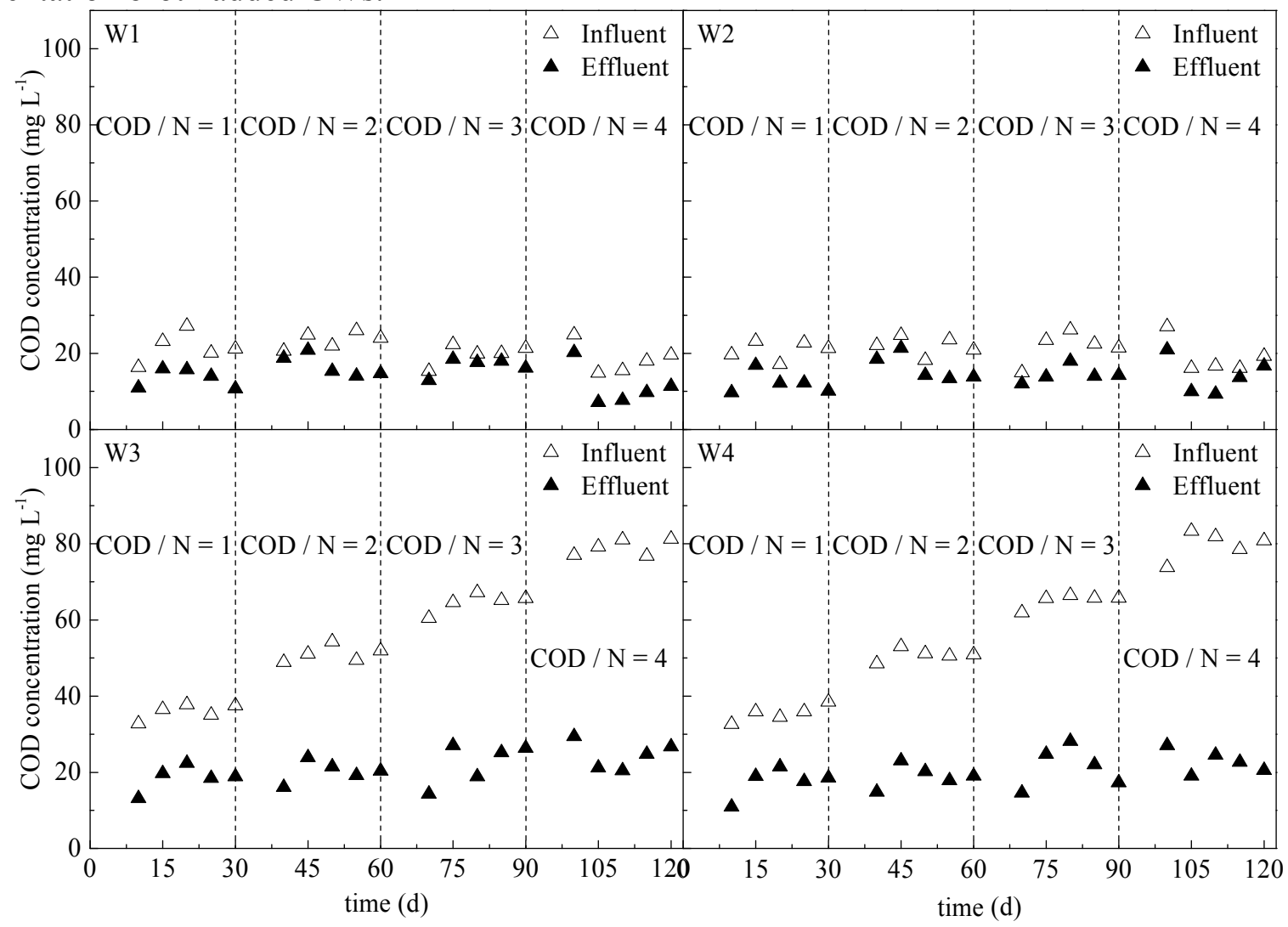

Fig. 2 Influent and effluent COD concentrations in four wetland microcosms

\subsection{Effluent COD.}

As the influent wastewater carbon is mostly oxidized in the aeration processes [2], the COD removal rates in $\mathrm{W} 1$ and $\mathrm{W} 2$ microcosms were only $1.59 \pm 0.78 \mathrm{~g} \mathrm{COD} \mathrm{m}^{-3} \mathrm{~d}^{-1}$ and $1.65 \pm 0.69 \mathrm{~g}$ COD m ${ }^{-3} \mathrm{~d}^{-1}$ over the period of this study, respectively.

Although the increase of $\mathrm{COD} / \mathrm{N}$ ratio (0-4) in $\mathrm{W} 3$ and $\mathrm{W} 4$ microcosms not only lead to the increase of organic load but also strengthen the oxygen-deficient status in CWs [11], the non-biodegradable organisms only account for a tiny fraction in cattail fermentation broth $(<7.3 \%)$ and the hydrophobic fraction can sink in the CWs by matrix adsorption. As a result, compared with $\mathrm{W} 1$ and W2 microcosms, the effluent COD concentrations increased 3.3-10.0 mg L ${ }^{-1}$ in W3 and W4 microcosms, and the effluent COD concentrations were less than $30 \mathrm{mg} \mathrm{L}^{-1}$ (Fig. 2), which further confirms the easy biodegradability of plant fermentation broth. Therefore, using cattail fermentation broth as additional carbon source to enhance nitrate removal in HSSF CWs is a kind of appropriate method.

\section{Conclusion}

The addition of cattail fermentation broth and the presence of Typha latifolia could improve the nitrate removal rate. As COD/N ratio increased from 0 to 3, the nitrate removal rate attributed to the plant increased from 0.09 to $0.29 \mathrm{~g} \mathrm{~N} \mathrm{~m}^{-3} \mathrm{~d}^{-1}$, but the nitrate removal proportion decreased from $27.3 \%$ to $10.7 \%$. And denitrification was always the dominant nitrate removal mechanism. 


\section{References}

[1]. Robert H. Kadlec, Scott D. Wallace. Treatment Wetlands, 2nd ed. CRC Press, 2009.

[2]. Harold L. Leverenz, Kristine Haunschild, Guy Hopes, et al. Anoxic treatment wetlands for denitrification. Ecological Engineering. Vol. 36 (2010) No. 11, p. 1544-1551.

[3]. P. Kuschk, A. Wießner, U. Kappelmeyer, et al. Annual cycle of nitrogen removal by a pilot-scale subsurface horizontal flow in a constructed wetland under moderate climate. Water Research. Vol. 37 (2003) No. 17, p. 4236-4242.

[4]. Ying-Feng Lin, Shuh-Ren Jing, Tze-Wen Wang, et al. Effects of macrophytes and external carbon sources on nitrate removal from groundwater in constructed wetlands. Environmental Pollution. Vol. 119 (2002) No. 3, p. 413-420.

[5]. Songliu Lu, Hongying Hu, Yingxue Sun, et al. Effect of carbon source on the denitrification in constructed wetlands. Journal of Environmental Sciences - China. Vol. 21 (2009) No. 8, p. 1036-1043.

[6]. Yue Wen, Yi Chen, Nan Zheng, et al. Effects of plant biomass on nitrate removal and transformation of carbon sources in subsurface-flow constructed wetlands. Bioresource Technology. Vol. 101 (2010) No. 19, p. 7286-7292.

[7]. Yi Chen, Yue Wen, Junwei Zhou, et al. Effects of cattail biomass on sulfate removal and carbon sources competition in subsurface-flow constructed wetlands treating secondary effluent. Water Research. Vol. 59 (2014), p. 1-10.

[8]. American Public Health Association, American Water Works, Water Environment Federation. Standard Methods for the Examination of Water and Wastewater, 20th ed. American Public Health Association, 1998.

[9]. Bruce E. Rittmann, Perry L. McCarty. Environmental Biotechnology: Principles and Applications. McGraw-Hill Book Company, 2001.

[10]. Noah P. Hume, Maia S. Fleming, Alexander J. Horne. Plant carbohydrate limitation on nitrate reduction in wetland microcosms. Water Research. Vol. 36 (2002) No. 3, p. 577-584.

[11]. Dong Cheol Seo, R.D. DeLaune. Fungal and bacterial mediated denitrification in wetlands: Influence of sediment redox condition. Water Research. Vol. 44 (2010) No. 8, p. 2441-2450.

[12]. Yongjun Zhao, Bo Liu, Wenguang Zhang, et al. Performance of pilot-scale vertical-flow constructed wetlands in responding to variation in influent $\mathrm{C} / \mathrm{N}$ ratios of simulated urban sewage. Bioresource Technology. Vol. 101(2010) No. 6, p. 1693-1700.

[13]. Robert H. Kadlec. Constructed Marshes for Nitrate Removal. Critical Reviews in Environmental Science and Technology. Vol. 42 (2012) No. 9, p. 934-1005.

[14]. Fu Yong Wu, Anna King Chuen Chung, Nora Fung Yee Tam, et al. Root exudates of wetland plants influenced by nutrient status and types of plant cultivation. International Journal of Phytoremediation. Vol. 14 (2012) No. 6, p. 543-553. 